\title{
EFFECTS OF TECHNOLOGICAL PARAMETERS ON THE MORPHOLOGICAL, MICROSTRUCTURAL AND MECHANICAL BEHAVIOR OF MICRO-ARC OXIDATION COATINGS ON Al SUBSTRATES
}

\author{
VPLIV TEHNOLOŠKIH PARAMETROV NA MORFOLOŠKE, \\ MIKROSTRUKTURNE IN MEHANSKE LASTNOSTI PREVLEK, \\ IZDELANIH S POSTOPKOM MIKRO-OBLOČNE OKSIDACIJE NA \\ PODLAGAH IZ ALUMINIJA
}

\author{
Wen Li ${ }^{1}$, Sheng Lei ${ }^{1}$, Yuanhao Xia ${ }^{1}$, Alidad Amirfazli ${ }^{1,2}$, Yalin Lu ${ }^{\text {* }}$ \\ ${ }^{1}$ School of Materials Engineering, Jiangsu University of Technology, 1801 Zhongwu Rd., Changzhou, Jiangsu, 213001 China \\ 2Department of Mechanical Engineering, York University, Toronto, ON, M3J 1P3, Canada \\ Prejem rokopisa - received: 2019-01-26; sprejem za objavo - accepted for publication: 2019-12-11
}

doi:10.17222/mit.2019.024

\begin{abstract}
Ceramic coatings were prepared in a silicate electrolyte on a substrate of 7075 aluminum alloy using micro-arc oxidation (MAO) technology. The effects of technological parameters such as voltage and reaction time on the surface morphology, microstructure and mechanical behavior of the prepared coatings were investigated using scanning electron microscopy (SEM), $\mathrm{X}$-ray diffraction (XRD), and friction-and-wear tests. The results showed that all these parameters played an important role in the quality of the coatings. In particular, the long reaction time, the suitable reaction voltage, and the high content of $\alpha-\mathrm{Al}_{2} \mathrm{O}_{3}$ resulted in the large thickness of the MAO film, the high binding strength, the large roughness and hardness, the small friction coefficient, and the small wear volume.

Keywords: voltage, micro-arc oxidation, friction properties, 7075 aluminum alloy, binding strength

Avtorji pričujočega članka opisujejo pripravo in karakterizacijo keramičnih prevlek v silikatnem elektrolitu na podlagi iz Al zlitine 7075. Prevleke so pripravljali s tehnologijo mikro-obločne oksidacije (MAO). Vpliv tehnoloških parametrov (kot sta npr.: napetost in reakcijski čas) na morfologijo površine, mikrostrukturo in mehanske lastnosti, so analizirali na pripravljenih prevlekah z vrstičnim elektronskim mikroskopom (SEM), z rentgensko difrakcijo (XRD) ter s testi trenja in obrabe. Rezultati preiskav so pokazali, da tehnološki parametri MAO igrajo pomembno vlogo za zagotavljanje izdelave kvalitetne prevleke. Še posebej dolg reakcijski čas, ustrezna napetost in visoka vsebnost $\alpha-\mathrm{Al}_{2} \mathrm{O}_{3}$, omogočajo izdelavo debelega MAO filma $\mathrm{z}$ veliko kohezijsko trdnostjo, veliko hrapavostjo in trdoto ter majhnim koeficientom trenja in majhno obrabo prevleke.

Ključne besede: električna napetost, mikro-obločna oksidacija, torne lastnosti, Al zlitina 7075, trdnost vezi med podlago in prevleko
\end{abstract}

\section{INTRODUCTION}

The 7075 aluminum alloys exhibit high toughness, hardness, specific strength and excellent processing properties. ${ }^{1}$ Such alloys are suitable as the component materials for ships and aircraft. To use such alloys under conditions of seawater or high speeds, excellent resistance to corrosion, wear and the high temperatures of component materials are required. ${ }^{2}$ However, the tribological properties of aluminum alloys are poor. ${ }^{3}$ With more and more requirements for lightweight mechanical moving components, the friction and wear performance has become an indicator of practical significance. ${ }^{4-5}$

The wear performance of aluminum alloys can be significantly improved by surface modifications. Common methods include micro-arc oxidation (MAO), chemical oxidation, electroplating, anodic oxidation,

*Corresponding author's e-mail:

lwjslg@126.com (Yalin Lu) laser cladding and thermal spraying. ${ }^{6}$ Among these methods, MAO is a simple and powerful surface-modification technique, which employs protective ceramic coatings on the surface of valve metals, such as $\mathrm{Al}, \mathrm{Mg}$, $\mathrm{Ti}$ as well as their alloys, and can be further divided into two categories: plasma electrolytic oxidation (PEO) and micro-plasma oxidation (MPO). ${ }^{7-10}$

Using the MAO treatments, a layer of alumina ceramic films or coatings on the surface of aluminum alloys can be formed. Such ceramic films and especially, coatings with a high hardness are very adhesive to a substrate, and hence can overcome a weakness such as the poor wear performance of aluminum alloys. ${ }^{11}$ At the same time, MAO has shown its many advantages, such as a simple and reliable process, reaction at room temperature, and environmental protection of the electrolyte without pollution, which suggests a variety of promising applications in industry. ${ }^{12}$

It has been generally recognized that the technological parameters of MAO can affect the quality of pre- 
pared coatings and their subsequent service performance. As one of the most important parameters of MAO, the voltage shows multiple effects on the microstructural and mechanical behavior of the prepared films or coatings. For example, M. Mohedano et al. ${ }^{13}$ investigated the effects of voltage on the in-situ growth films for AA2024 aluminum alloys. Four MAO films were developed at different voltages $(350,400,450$, and 500) $\mathrm{V}$ and a significant increase in thickness with voltage was found. MAO was also known to be used to improves the surface hardness and friction resistance of aluminum alloys. For example, L. R. Krishna et al. ${ }^{14}$ studied the effects of current density, reaction time and reaction temperature on the friction behavior of 7075 aluminum alloys. They revealed that the current density and reaction time had a great influence on the friction properties of the film layer, whereas the influence of the reaction temperature on the friction properties of the film layer could be neglected. Furthermore, G. Sabatini et al. ${ }^{15}$ studied the wear resistance of oxide layers grown on aluminum alloy surfaces under MAO treatment conditions. It was demonstrated that the MAO treatments could significantly improve the wear resistance of aluminum alloys under low loads. However, under the action of high loads, the transfer layer was unstable, and the hardness of the MAO layer and the bearing capacity of the matrix became the main factors for the wear resistance.

To overcome the above weakness, efforts have been devoted to the effects of various technological parameters in recent years. For example, A. Melhem et al. ${ }^{16}$ found that the thickness of the MAO film layer increased with the electrode spacing, but the wear and corrosion performance of such a film have not been well addressed. M. Mohedano et al. ${ }^{17}$ investigated the effect of voltage on the corrosion resistance of MAO coatings. It was shown that for the same reaction time, the higher the voltage, the thicker the film layer and the better the corrosion resistance, but the friction behavior of the film has not been addressed. E. Arslan et al. ${ }^{18}$ studied the effect of temperatures on the tribological performance of MAO coatings. They revealed that both the wear rate and the friction coefficient decreased with the test temperatures, but the mechanism for such behavior has remained unclear.

At present, for aluminum alloys, most of the literature reports on MAO focus on the corrosion performance and welding properties. ${ }^{19}$ The investigations on tribological behavior such as friction and wear performance are still few. For example, J. V. Zhang et al. ${ }^{20}$ found that the roughness of the MAO coating increased slowly with the duty cycle, but the friction coefficient of the MAO layer decreased. When the duty ratio was $40 \%$, the wear rate was the smallest. M. Trevino et al. ${ }^{21}$ investigated the effect of the thickness of the MAO layer on the wear resistance. When the film thickness was $100 \mathrm{um}$, the amount of wear was the smallest. H. J. Xie et al. ${ }^{22}$ studied the effect of different MAO times on the surface wear properties of the A365 aluminum alloy. When the MAO time was $480 \mathrm{~s}$, the wear rate of the film was the lowest. Here it is worth noting that although the above-mentioned studies have started to investigate the effects of some technological parameters and achieved some significant results, a thorough understanding on the relationships between the technological parameters and morphology, the microstructures and the mechanical properties and, especially, the involved mechanisms has remained unavailable. To this end, comprehensive research and, in particular, systematic investigations of the complete effects of all the involved technological parameters are necessary.

In this work we prepared a ceramic on Al substrates and investigated the effects of the MAO voltage and reaction time on the surface morphology, microstructure and mechanical behavior using scanning electron microscopy (SEM), X-ray diffraction (XRD), and frictionand-wear tests, aiming at the establishment of their correlations and the achievement of the responsible mechanisms.

\section{EXPERIMENTAL PART}

\subsection{Substrate materials}

7075 aluminum alloy cubes (the nominal composition in weight percent: $0.4 \% \mathrm{Si}, 0.5 \% \mathrm{Fe}, 1.2-0.4 \%$ $\mathrm{Cu}, 0.3 \% \mathrm{Mn}, 2.1-2.9 \% \mathrm{Mg}, 0.18-0.28 \% \mathrm{Cr}$, 5.1-6.1\% Zn, $0.2 \% \mathrm{Ti}$ and $\mathrm{Al}$ bal.) with an edge length of $10 \mathrm{~mm}$ were used as substrates. Before the MAO treatments, the specimens were gradually sanded using waterproof abrasive papers from 400 \# to 1200 \#, rinsed in distilled water, and finally dried in a stream of warm air.

\subsection{MAO processing}

A direct current power supply (WHD-30 made by Harbin Institute of Technology) was used to prepare the MAO coatings on the aluminum alloy surface. The 7075 aluminum alloy samples were used as an anode, with the stainless-steel sheet as the cathode. Constant-voltage mode was selected for the MAO treatment. The forward voltage varied from $410 \mathrm{~V}$, to $450 \mathrm{~V}$, to $490 \mathrm{~V}$. The reverse voltage was $70 \mathrm{~V}$ at a frequency of $500 \mathrm{~Hz}$ and a duty ratio of $40 \%$. The time of the MAO varied from $10 \mathrm{~min}$, to $30 \mathrm{~min}$, to $50 \mathrm{~min}$. The electrolytes consisted of $1 \mathrm{~g} \mathrm{~L}^{-1} \mathrm{KOH}, 6 \mathrm{~g} \mathrm{~L}^{-1} \mathrm{NaSiO}_{3}$ and $0.5 \mathrm{~g} \mathrm{~L}^{-1} \mathrm{Na}_{2} \mathrm{~B}_{4} \mathrm{O}_{7}$. The electrolyte was mixed with a magnetic stirrer. The solution temperature was kept below $50{ }^{\circ} \mathrm{C}$ during the MAO processes.

\subsection{Characterizations}

The surface micro-morphology of the coatings was observed by using scanning electron microscopy (SEM, Sigma 500). The bottom of every sample was polished and attached with conductive tape. The phase composi- 
tions of the MAO coatings were analyzed using $\mathrm{x}$-ray diffraction (XRD, D8ADVANCE), scanning at $2 \theta$ values range from $10^{\circ}$ to $90^{\circ}$ with a speed of $5^{\circ} \mathrm{min}^{-1}$. The film thicknesses were measured with a TT210 coating thickness gauge.

\subsection{Hardness}

The hardness was measured using a micro Vickers hardness tester. The bottom surface of the MAO samples was polished, the diamond indenter was loaded with a force of $200 \mathrm{~N}$, the indenter was pressed into the sample for $15 \mathrm{~s}$, the surface of the sample was magnified 400 times by a microscope, the area of the rhomboid pit left by the diamond indenter was measured using software, and finally the hardness was obtained.

\subsection{Friction-and-wear tests}

The tribological properties of the coatings were tested on a MDW-02 high-frequency reciprocating fatigue friction and wear testing machine with a reciprocating length of $6 \mathrm{~mm}$, and the friction coefficient measurement was conducted under loading force of $5 \mathrm{~N}$. The micro-morphology of the friction trace was observed using a 3D optical profilometer (NANOVEA PS50) with a projection area of $4 \mathrm{~mm}^{2}$. The roughness of the coatings was also recorded.

\subsection{Binding strength}

The binding strength between the coating and the substrate of aluminum alloys was tested using a WS-2005 Automatic scratching instrument for coating adhesion. During the scratch test, the load range from $0.25 \mathrm{~N}$ to $70 \mathrm{~N}$ was stressed continuously and evenly by the pressure head. The loading rate of the pressure head was $70 \mathrm{~N} \mathrm{~min}{ }^{-1}$. The moving speed of the squeeze head was set at $0.1 \mathrm{~mm} \mathrm{~s}^{-1}$ with the scratch length left on sample surface of $4 \mathrm{~mm}$. The scratch test on the coating was implemented with a conductive block so the binding strength can be measured accurately.

\section{RESULTS AND DISCUSSION}

\subsection{Surface analysis}

Figure 1 shows the surface micromorphology of the MAO coatings prepared under different constant voltages. It can be seen that the micro-pores appeared on all the coatings. In sample group $1 \mathrm{a}, 1 \mathrm{~b}$ and $1 \mathrm{c}$, group $2 \mathrm{~d}$, $2 \mathrm{e}, 2 \mathrm{f}$ and group $3 \mathrm{~g}, 3 \mathrm{~h}$ and $3 \mathrm{i}$, the ceramic coatings were prepared under the same voltage for $(410,450$, and 490) $\mathrm{V}$ with different times. At the same voltage, the pores formed by MAO became larger with time, and the porosity decreased with time. When the voltage was small, such as group 1, the spacing between the holes was large. This happened because during the growth of

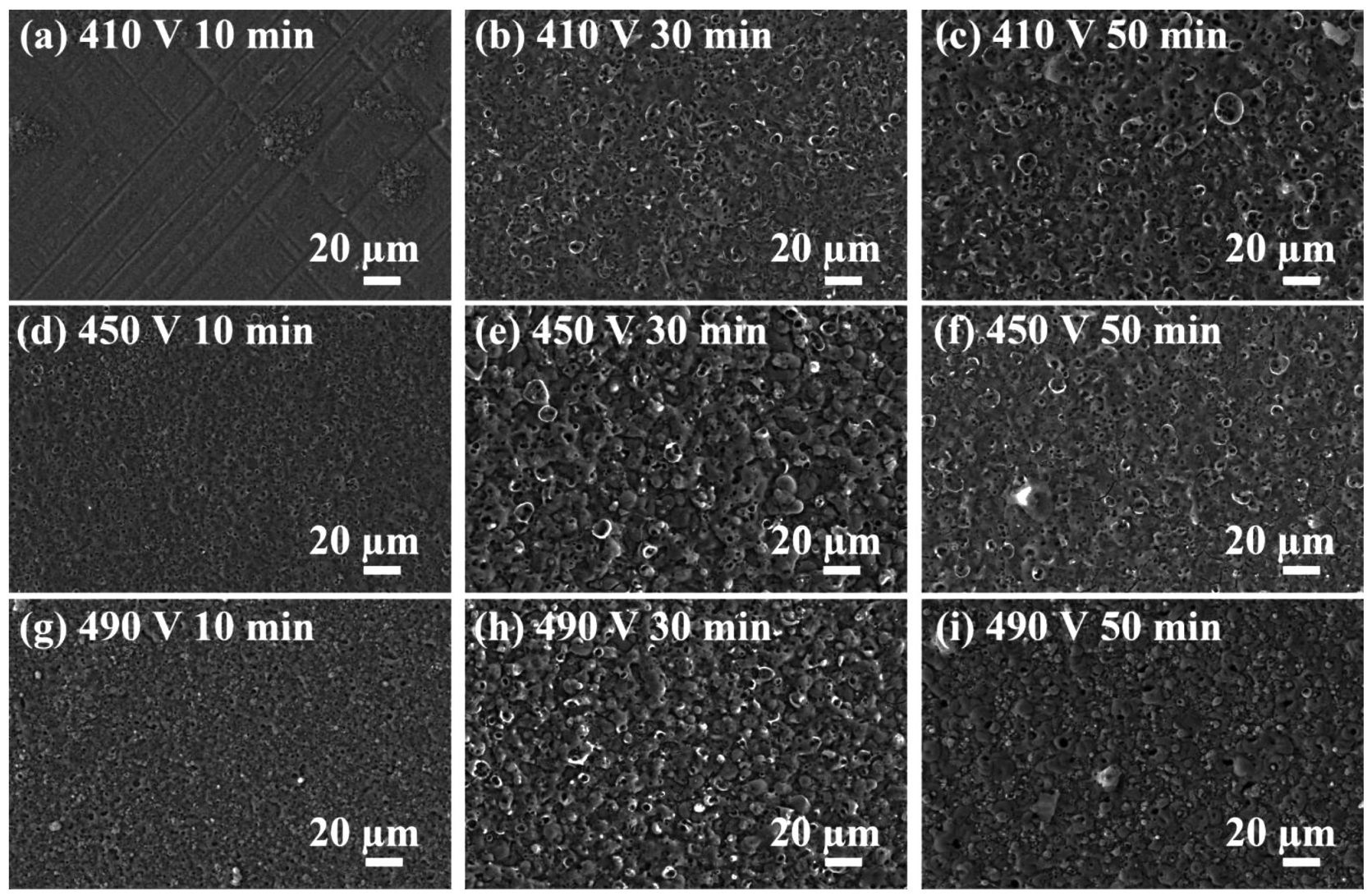

Figure 1: Micromorphology of MAO coatings with: a) $410 \mathrm{~V} 10 \mathrm{~min}$, b) $410 \mathrm{~V} 30 \mathrm{~min}$, c) $410 \mathrm{~V} 50 \mathrm{~min}$, d) $450 \mathrm{~V} 10 \mathrm{~min}$, e) $450 \mathrm{~V} 30 \mathrm{~min}$, f) $450 \mathrm{~V} 50 \mathrm{~min}$, g) $490 \mathrm{~V} 10 \mathrm{~min}, \mathrm{~h}) 490 \mathrm{~V} 30 \mathrm{~min}$, i) $490 \mathrm{~V} 50 \mathrm{~min}$ 

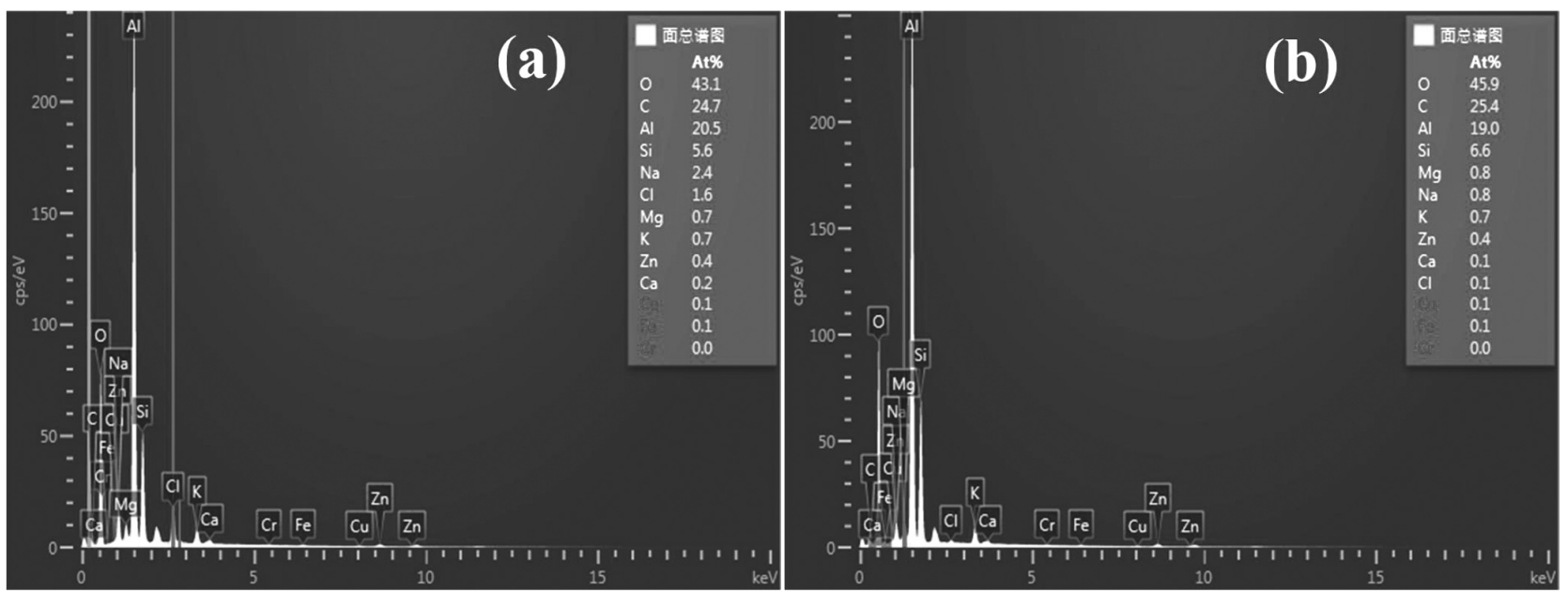

Figure 2: EDS of MAO coatings with: a) $490 \mathrm{~V} 30 \mathrm{~min}$, b) $490 \mathrm{~V} 50 \mathrm{~min}$

the film layer, the melts at the main channel ports flowed around and covered the small MAO channels, the breakthrough voltages of the small channels were small, and the channels could not be broken down again after being covered. Only large discharge channels were left. In group 2, the surface of Figure 1d was the finest, which may be that the MAO time was short, the discharge phenomenon was active, and the discharge paths were more, and the formed pores were small and numerous. With the extension of time, the diameter of the hole on the surface of Figure 1f was significantly larger than that formed under $410 \mathrm{~V}$, and the number of discharge channels were also reduced a lot. When the voltage was large, such as group 3, the diameter of the hole left by the discharge channel was much larger than that of the small voltage. When the reaction time was $30 \mathrm{~min}$, the fine cracks appeared on the surface, whereas when the reaction time was $50 \mathrm{~min}$, a new layer of molten material accumulated on the surface, covering the previous cracks and making the surface smooth. Comparing Figure 1i with Figure 1h, the oxygen atomic ratio increased by $2.8 \%$, as shown in Figure 2, which suggested that a new layer of oxide was formed on the surface.

Figure 3 shows the roughness and thickness of the MAO coatings prepared under different voltages. When the reaction time was short, the excessively small voltage could not effectively grow the film layer, and the surface roughness was large. The excessive voltage caused the film layer around the discharge channel to grow faster and the surface roughness was large. When the time reached $30 \mathrm{~min}$, the surface roughness with a reaction voltage of $450 \mathrm{~V}$ reached the maximum. When the time was large, the discharge phenomens were relatively weakened, the melt around the discharge channel diffused around, and the surface roughness was lowered from $51 \mu \mathrm{m}$ to $20 \mu \mathrm{m}$. The thickness of the film was generally increasing and the growth rate was gradually decreasing with the increase of the reaction time. The thickness of the film increased as the voltage increased.

\subsection{Phase analysis}

Figure 4 shows the X-ray diffraction (XRD) patterns of the coatings prepared under different voltages for $50 \mathrm{~min}$. It is clear that the MAO coatings were mainly composed of two crystal phases, $\alpha-\mathrm{Al}_{2} \mathrm{O}_{3}$ and $\gamma-\mathrm{Al}_{2} \mathrm{O}_{3}$. The specimen under voltages of $410 \mathrm{~V}$ and $450 \mathrm{~V}$, their
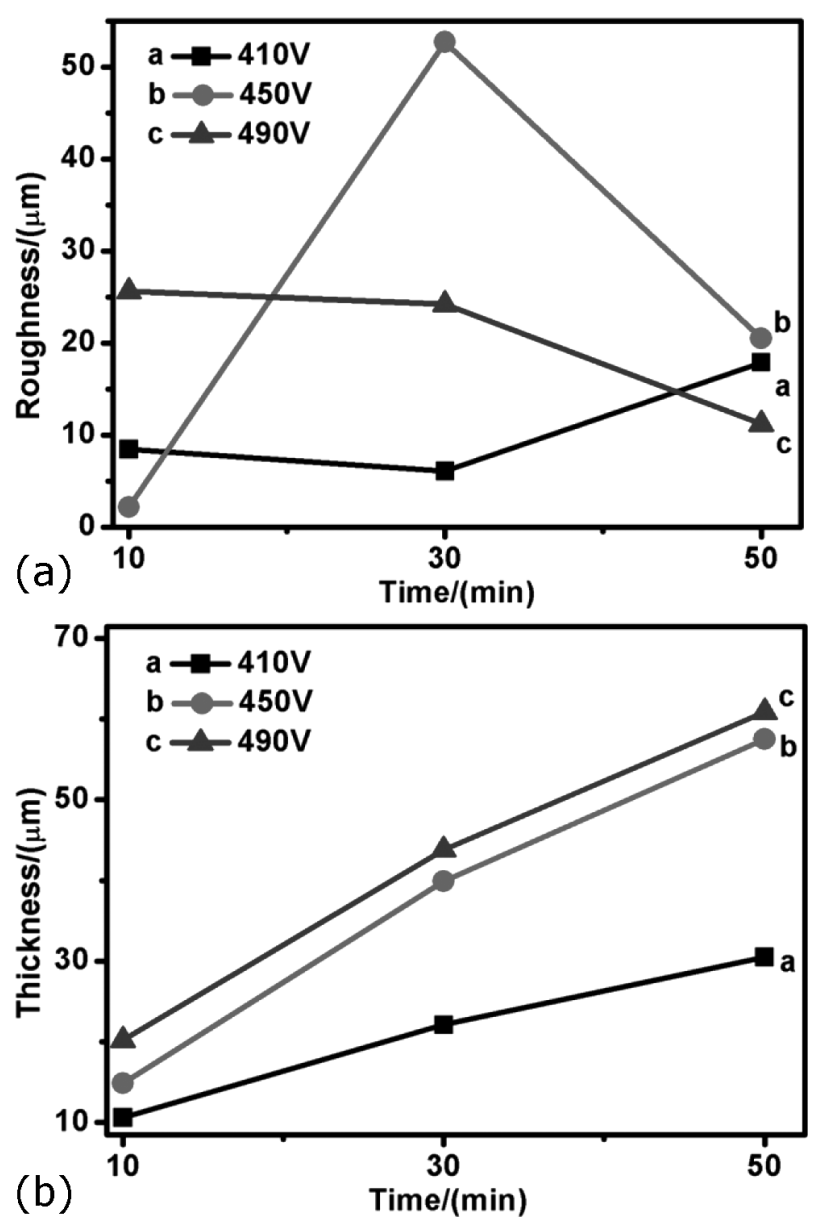

Figure 3: Roughness and thickness of MAO coating 


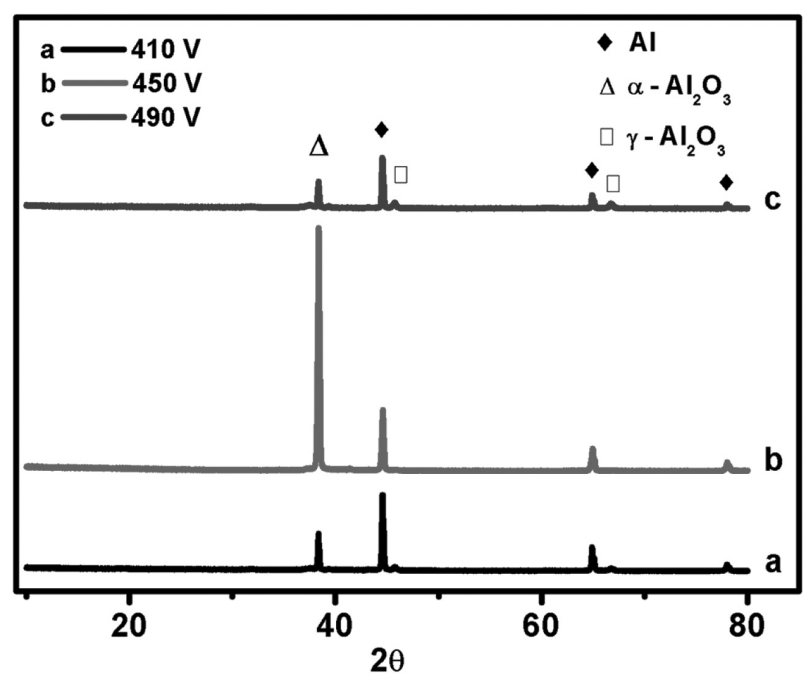

Figure 4: XRD of MAO coating

diffraction peaks of $\gamma-\mathrm{Al}_{2} \mathrm{O}_{3}$ and $\mathrm{Al}$ were strong, while the peaks of $\alpha-\mathrm{Al}_{2} \mathrm{O}_{3}$ were very weak. However, when the voltage was $450 \mathrm{~V}$, the intensity from the crystal peak of $\alpha-\mathrm{Al}_{2} \mathrm{O}_{3}$ increased significantly, while the diffraction peaks of $\mathrm{Al}$ became weak.

In the MAO process, the alumina film could be transformed into $\gamma-\mathrm{Al}_{2} \mathrm{O}_{3}$ at high temperatures. If the temperature increased to $1000{ }^{\circ} \mathrm{C}$, unstable $\gamma-\mathrm{Al}_{2} \mathrm{O}_{3}$ could be converted into $\alpha-\mathrm{Al}_{2} \mathrm{O}_{3}$. The appearance of $\alpha-\mathrm{Al}_{2} \mathrm{O}_{3}$ also indicated an extremely high reaction temperature in the arc discharge area. So, with increasing the constant voltage, the intensity of diffraction peak of $\alpha-\mathrm{Al}_{2} \mathrm{O}_{3}$ also increased. When the voltage was $410 \mathrm{~V}$, the arc discharge phenomenon was not obvious, so $\alpha-\mathrm{Al}_{2} \mathrm{O}_{3}$ could not be formed on the coating although the diffraction peak of $\gamma-\mathrm{Al}_{2} \mathrm{O}_{3}$ was very strong. The intensity of the diffraction peak of $\alpha-\mathrm{Al}_{2} \mathrm{O}_{3}$ was the highest when the voltage was $450 \mathrm{~V}$. When the voltage reached $490 \mathrm{~V}$, the intensity of the diffraction peaks of $\alpha-\mathrm{Al}_{2} \mathrm{O}_{3}$ and $\gamma-\mathrm{Al}_{2} \mathrm{O}_{3}$ significantly decreased and the peaks of $\mathrm{Al}$ become lower,

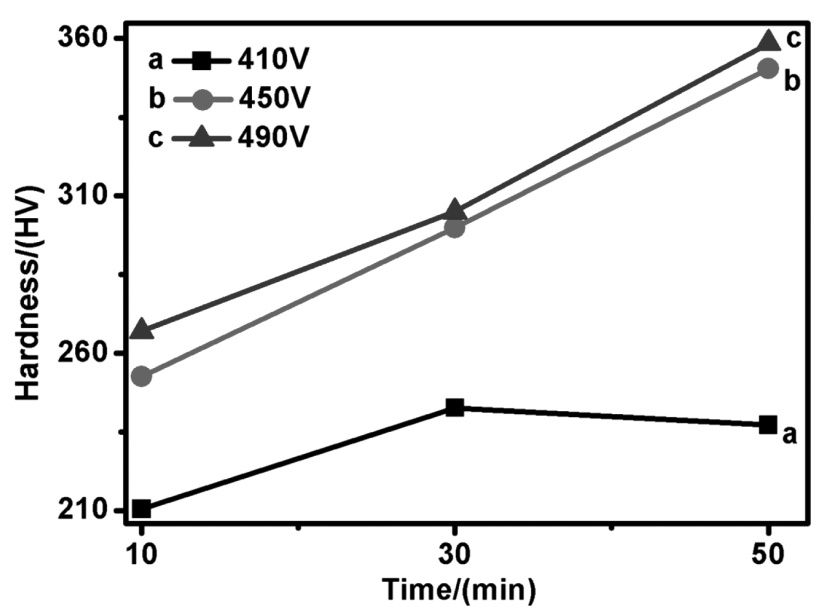

Figure 5: Hardness of MAO coating because the transformation process was hindered by the high temperatures produced by the arc light.

\subsection{Hardness}

Figure 5 shows the hardness of the MAO coatings prepared under voltages of $(410,450$, and 490) V. The substrate without the coating showed a hardness of 180 HV. However, the hardness of the MAO coating was increased twice compared with the substrate. The hardness of the film layer increased as the reaction voltage increased. The reaction voltage increased from $410 \mathrm{~V}$ to $450 \mathrm{~V}$, the hardness increased by $45 \mathrm{HV}$, and the rate of increase was $1.125 \mathrm{HV} / \mathrm{V}$. The reaction voltage increased from $450 \mathrm{~V}$ to $490 \mathrm{~V}$, the hardness increased by $8 \mathrm{HV}$, and the rate of increase was $0.2 \mathrm{HV} / \mathrm{V}$, indicating that the rate was greatly reduced. At the low voltage, the film layer was thin, the hardness was low. When the voltage was $490 \mathrm{~V}$, it can be seen from the electron mimeographs that the surface had fine defects when the reaction time was $30 \mathrm{~min}$, so the hardness did not reach the highest value. As the time passed, the surface defects were compensated and the hardness continued to increase. At the high voltages, the thickness of the film layer was large, so the hardness was increased.

\subsection{Binding strength}

As shown in Figure 6, the changing trend of the binding strength at each voltage was similar. The binding strength increased gradually. The binding strength with a voltage of $450 \mathrm{~V}$ was the strongest, whereas the binding strength of the voltage of $410 \mathrm{~V}$ was the weakest. This happened because the binding strength strongly depended on the proportion of $\alpha-\mathrm{Al}_{2} \mathrm{O}_{3}$. Moreover, the reaction of MAO was low, the matrix could not completely react with the ions in the solution and the content of $\alpha-\mathrm{Al}_{2} \mathrm{O}_{3}$ was low, so the high-strength film could not be formed under the voltage of $410 \mathrm{~V}$. The arc discharge phenomenon was intense and the ceramic membrane was destroyed by the excessive voltage, so the growth rate of

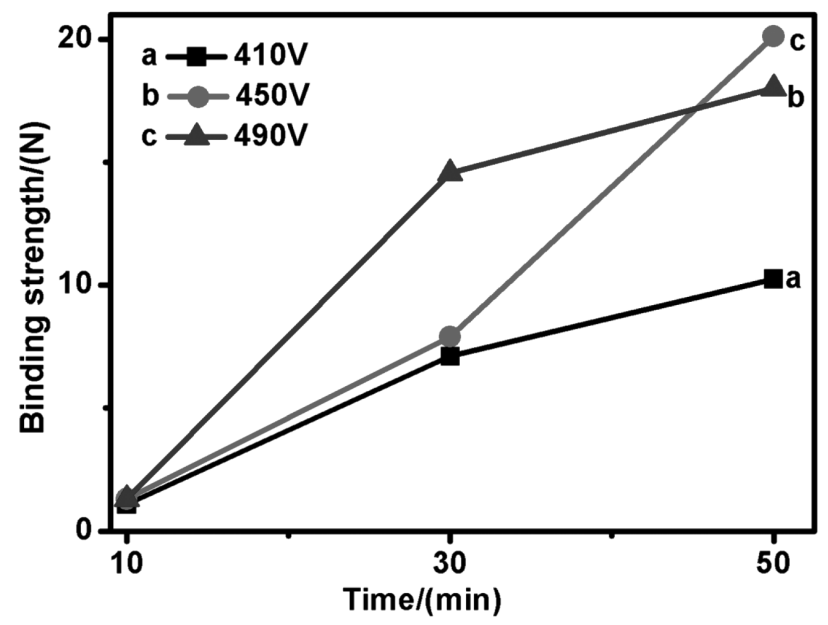

Figure 6: Binding strength of MAO coating 
W. LI et al.: EFFECTS OF TECHNOLOGICAL PARAMETERS ON THE MORPHOLOGICAL, MICROSTRUCTURAL AND ...
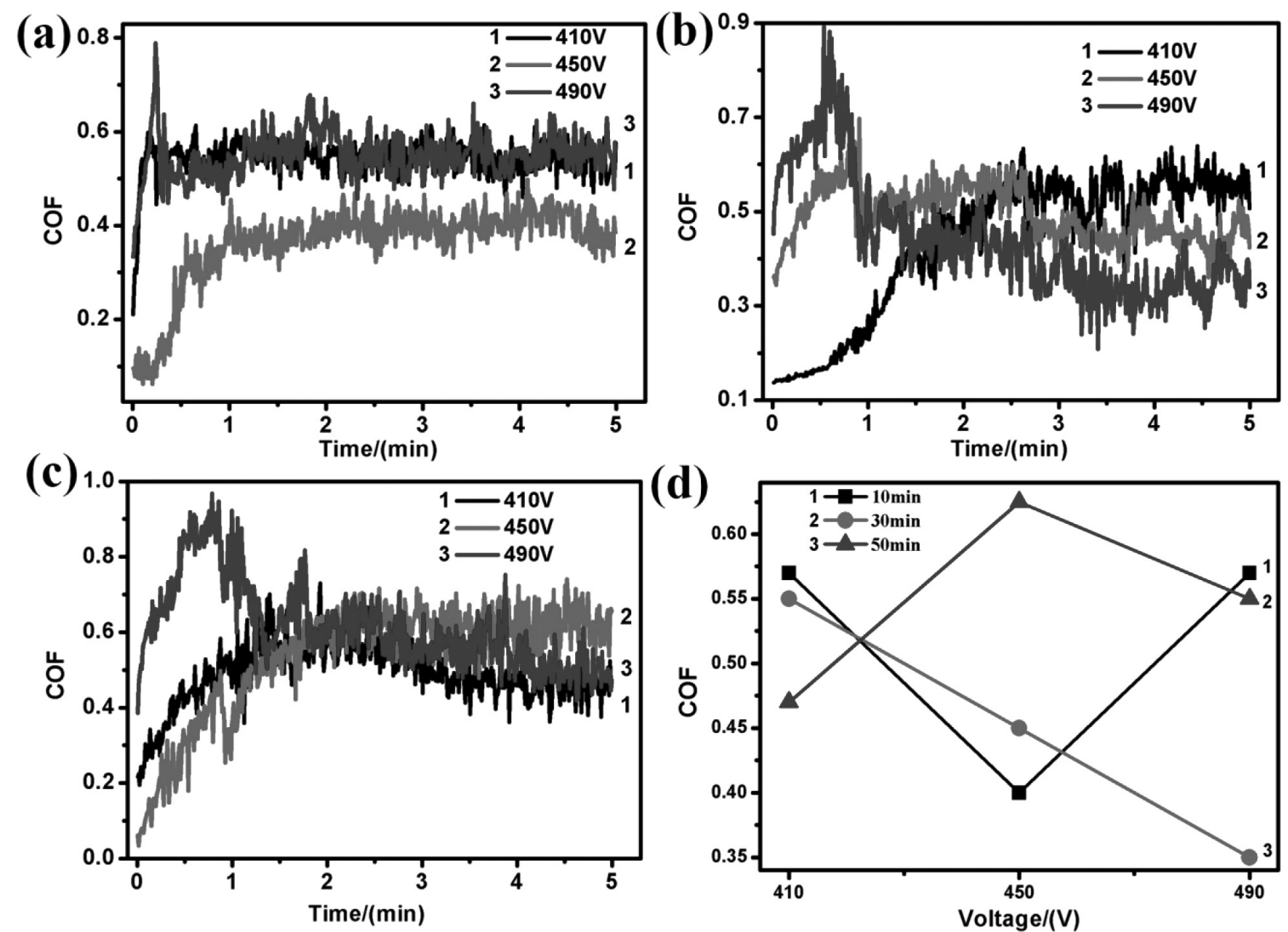

Figure 7: Coefficient of friction of MAO coating with reaction time: a) $10 \mathrm{~min}$, b) $30 \mathrm{~min}$, c) $50 \mathrm{~min}$ and d) voltage

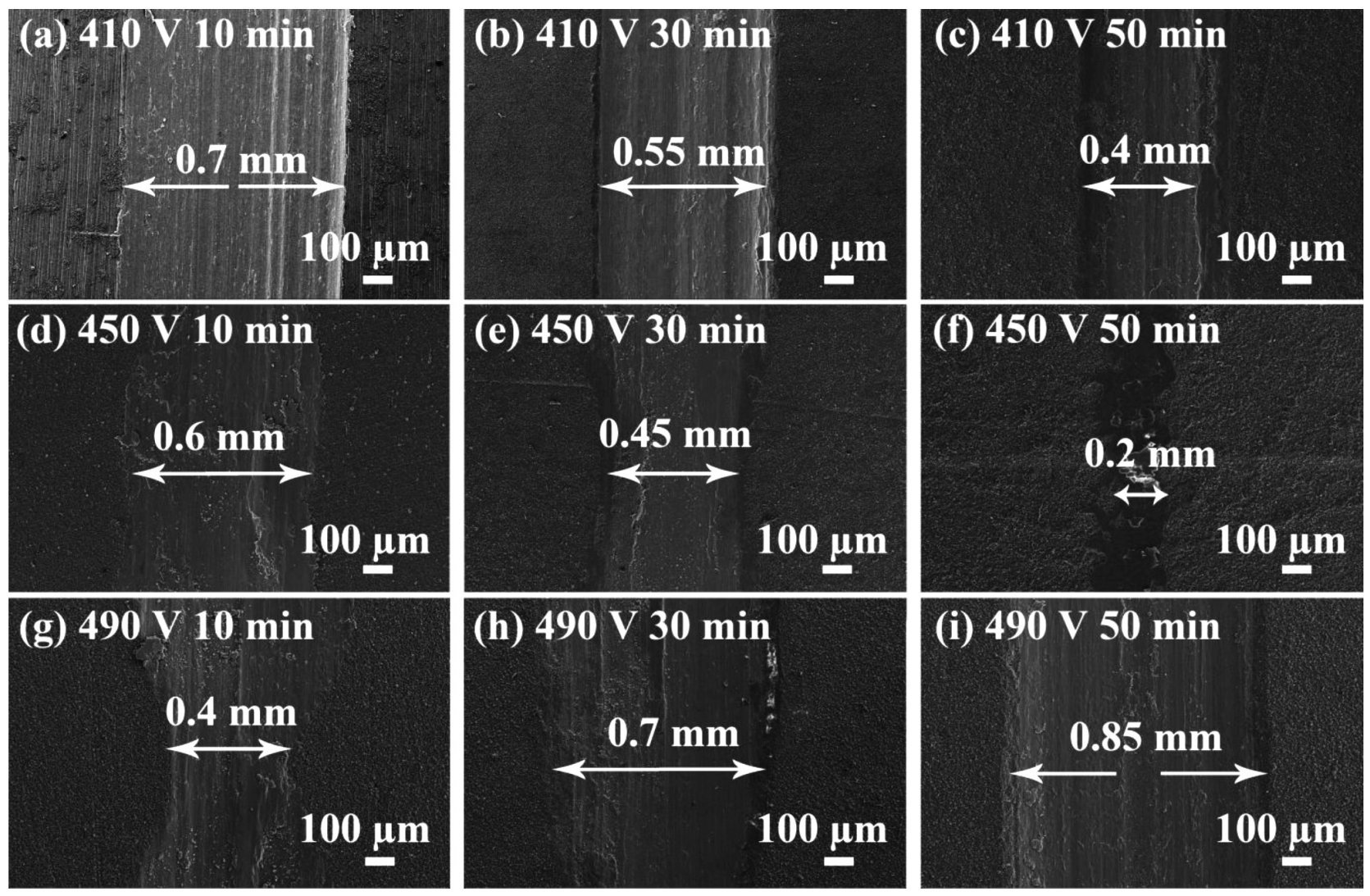

Figure 8: Micromorphology of friction and wear with coatings with: a) $410 \mathrm{~V} 10 \mathrm{~min}$, b) $410 \mathrm{~V} 30 \mathrm{~min}$, c) $410 \mathrm{~V} 50 \mathrm{~min}$, d) $450 \mathrm{~V} 10 \mathrm{~min}$, e) $450 \mathrm{~V} 30 \mathrm{~min}, \mathrm{f}) 450 \mathrm{~V} 50 \mathrm{~min}, \mathrm{~g}) 490 \mathrm{~V} 10 \mathrm{~min}, \mathrm{~h}) 490 \mathrm{~V} 30 \mathrm{~min}$ and i) $490 \mathrm{~V} 50 \mathrm{~min}$ 
the binding strength decreased under the voltage of $490 \mathrm{~V}$.

\subsection{Tribological behavior}

As shown in Figure 7, the friction-coefficient curve eventually tended to be stable, and the curve in Figure 7a was the most obvious. As seen, the friction coefficient between $410 \mathrm{~V}$ and $490 \mathrm{~V}$ raised sharply in the initial stage and then tended to be stable. The friction coefficient at $450 \mathrm{~V}$ raised slowly, and the final value of the friction coefficient was also significantly lower than the other two curves, and the roughness was the minimum. In Figure 7b, the curve of $490 \mathrm{~V}$ had the largest slope, which might be due to the excessive voltage and the loose surface. The curve for $450 \mathrm{~V}$ also showed a large slope due to the large surface roughness. In Figure 7c, the $490 \mathrm{~V}$ curve showed a large peak, which might be caused by its too loose surface structure, and the friction coefficient tended to be stable after the surface was scratched. The final plateau of the coefficient of friction could hardly indicate the independence of the voltage, reaction time and roughness. Under the same reaction voltage, the surface roughness was proportional to the variation trend of the friction coefficient with the increase of the reaction time. As shown in Figure 7d, the coefficient of friction decreased linearly with increasing voltage when the reaction time was $30 \mathrm{~min}$. For a reaction voltage of $450 \mathrm{~V}$ and a reaction time of $50 \mathrm{~min}$, the coefficient of friction reached its maximum value. At the same time, under these conditions, the scratch width was the narrowest (only $0.2 \mathrm{~mm}$ shown in Figure 8f). Generally, the smaller the friction coefficient, the better the wear resistance. Here it is worth noting that Yang et al. obtained the best wear resistance with the lowest friction coefficient, ${ }^{23}$ but the scratch width was the smallest as the friction coefficient was the largest in the present work.

The micromorphologies of the friction and wear with coatings prepared under different voltages are shown in Figure 8. In Figures 8a to 8c, it can be observed that the width of the rubbing trace was significantly reduced, the width was reduced from $0.7 \mathrm{~mm}$ to $0.4 \mathrm{~mm}$, and the contour of the rubbing trace of Figures 8c was somewhat fluctuated. For a long reaction time and a high reaction temperature, $\gamma-\mathrm{Al}_{2} \mathrm{O}_{3}$ was transformed into $\alpha-\mathrm{Al}_{2} \mathrm{O}_{3}$, and the MAO film was stable. As a result, the hardness became high, leading to the narrow film mark. The irregularity of the wear scar also indicated that some of the (a) $410 \mathrm{~V} 10 \mathrm{~min}$

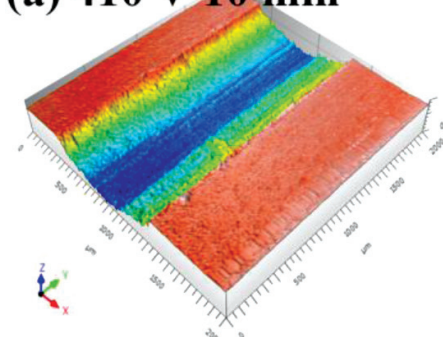

(d) $450 \mathrm{~V} 10 \mathrm{~min}$

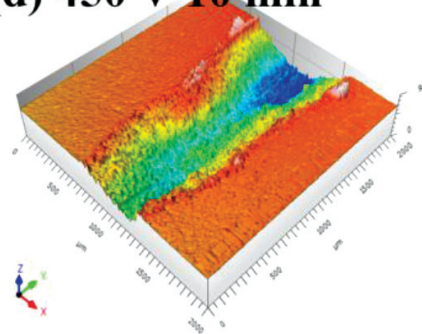

(g) $490 \mathrm{~V} 10 \mathrm{~min}$

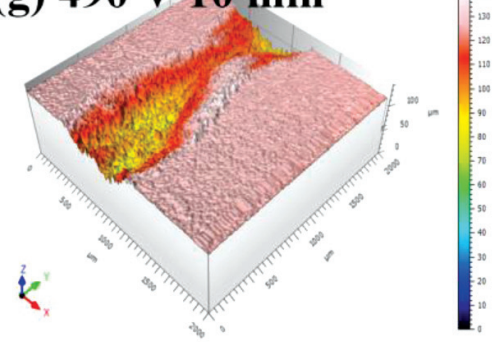

(b) 410 V 30 min

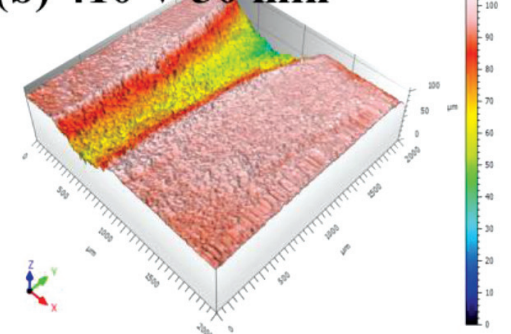

(e) $450 \mathrm{~V} 30 \mathrm{~min}$

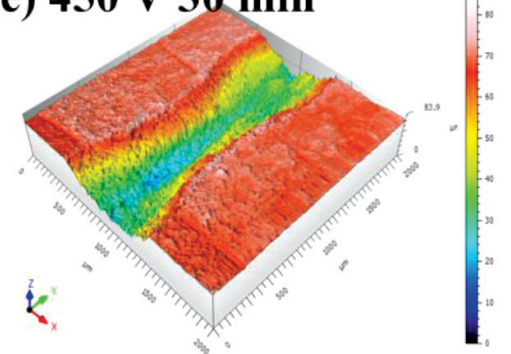

(h) $490 \mathrm{~V} 30 \mathrm{~min}$

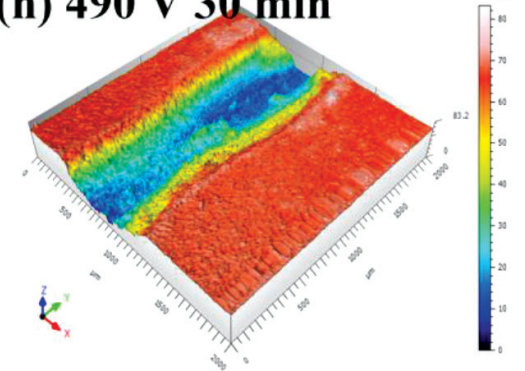

(c) 410 V 50 min

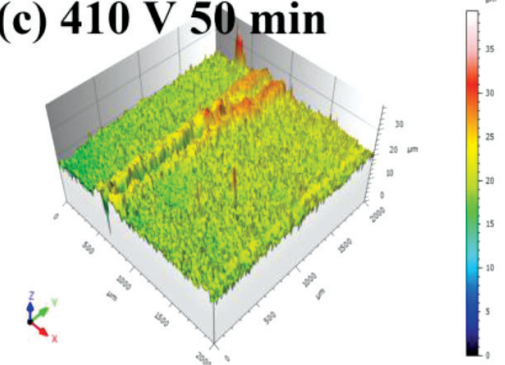

(f) $450 \mathrm{~V} 50 \mathrm{~min}$

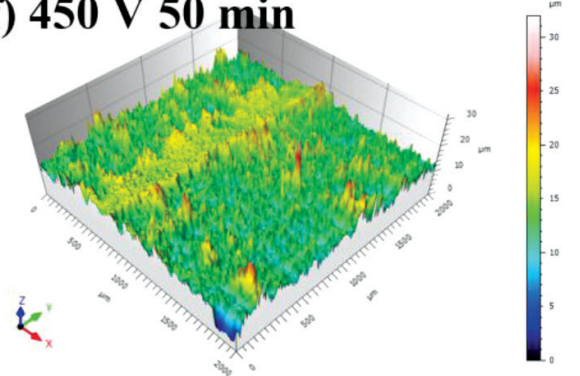

(i) $490 \mathrm{~V} 50 \mathrm{~min}$

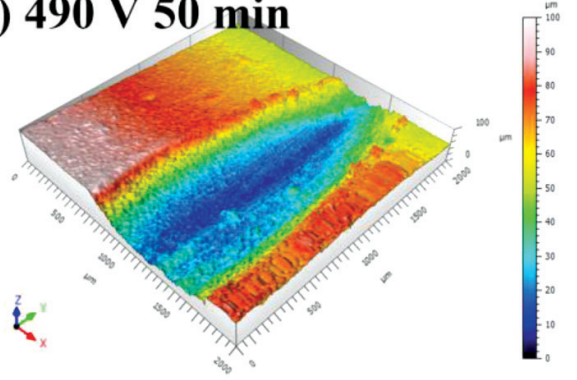

Figure 9: 3D of friction and wear with coatings with: a) $410 \mathrm{~V} 10 \mathrm{~min}$, b) $410 \mathrm{~V} 30 \mathrm{~min}, \mathrm{c}) 410 \mathrm{~V} 50 \mathrm{~min}$, d) $450 \mathrm{~V} 10 \mathrm{~min}$, e) $450 \mathrm{~V} 30 \mathrm{~min}$, f) $450 \mathrm{~V} 50 \mathrm{~min}, \mathrm{~g}) 490 \mathrm{~V} 10 \mathrm{~min}, \mathrm{~h}) 490 \mathrm{~V} 30 \mathrm{~min}$ and i) $490 \mathrm{~V} 50 \mathrm{~min}$ 
$\gamma-\mathrm{Al}_{2} \mathrm{O}_{3}$ was left. In Figures 8d to $8 \mathbf{8}$, the trend of the change of the rubbing marks was also gradually decreased in width, the width was reduced from $0.6 \mathrm{~mm}$ to $0.2 \mathrm{~mm}$. The wear profile was not a regular straight line perhaps because the adhesive force of the intermediate film was better, and it was not easy to wear. In Figures $\mathbf{8 g}$ to $\mathbf{8 i}$, the trend of the rubbing marks was gradually increased in width, which was increased from $0.4 \mathrm{~mm}$ to $0.85 \mathrm{~mm}$. The rubbing marks were also irregular, and the outermost MAO layer was loose. When the reaction voltage was too large, the thickness of the loose layer was large, the MAO film was hard and brittle, i.e., it is easy to wear, and the scratch was wide and deep.

\subsection{Wear behavior}

Three-dimensional appearances of friction and wear were shown in Figure 9. The large variation in the color for the graphs showed that the surface roughness of the film layer was large. The characterizations of the 3D morphology corresponded to the microscopic morphology of the friction, and the perspective view intuitively showed the width of the friction trace and the amount of wear volume. Figure 9c had a small width of abrasion marks, forming uplifted deposits with a large depth and low surface hardness. Since the surface hardness was low, the binding strength was good, the thickness of the outermost loose layer should be small, and the dense layer can prevent damage to the MAO film. As a result, a canyon-like wear scar was formed. The outline morphology of Figure $9 f$ basically could not change much, the wear mark depth was shallow, and the wear amount was the least. The vivid color of Figure 9i indicated that the film layer had a large height drop. When the voltage was $490 \mathrm{~V}$, the color of the wear mark became darker and darker.

Wear volume of MAO coatings prepared under different voltages are shown in Figure 10. At a voltage of $410 \mathrm{~V}$, the oxide film was formed slowly. Therefore, the film thickness was relatively small, but there was a small

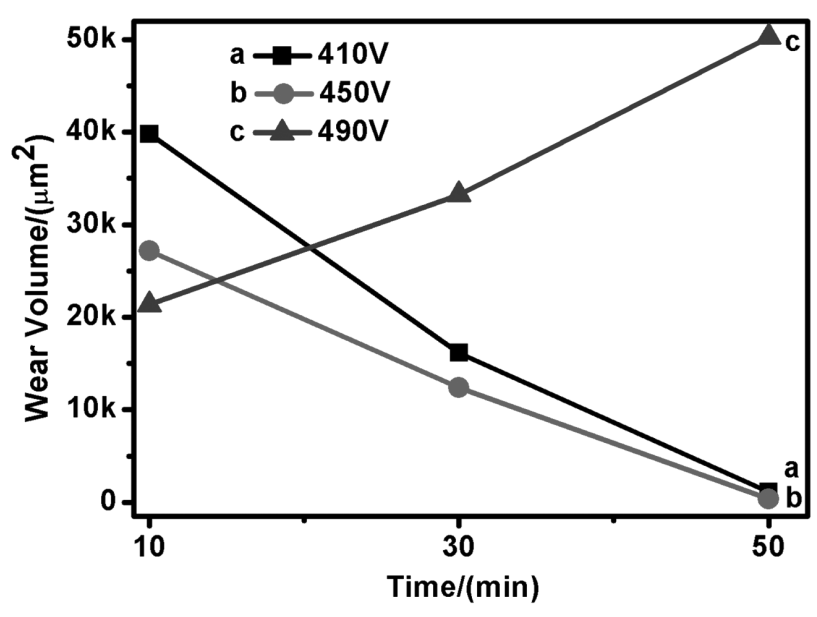

Figure 10: Wear volume of MAO coating roughness and the obtained wear volume was small. When the reaction voltage was $450 \mathrm{~V}$, the wear volumes decreased linearly. High hardness and high $\alpha-\mathrm{Al}_{2} \mathrm{O}_{3}$ phase content might be the reason for such a small amount of wear volume. When the voltage reached $490 \mathrm{~V}$, the intense arc discharge hindered the formation of a dense oxide film and destroyed the already formed ceramic film, so the wear volumes were large.

When the reaction time was $10 \mathrm{~min}$, the wear volumes were large and the binding strengths were the lowest, so the friction ball could wear through the whole ceramic film. At $30 \mathrm{~min}$, both the binding strength and the film thickness were increased, the wear volume was reduced, and the wear was effectively resisted. At $50 \mathrm{~min}$, the high-voltage arc discharge for a long time formed a new breakdown channel and destroyed the original dense layer. The increase rate of the binding strength decreased and the wear volume was increased. A reasonable increase of the micro-arc oxidation voltage and reaction time could effectively improve the binding strength, formed a smooth ceramic film, and suppressed the friction and wear. However, too high a voltage could also compromise the compactness and surface roughness of the original film layer, therefore increasing the friction and wear volume. When the voltage was $450 \mathrm{~V}$ and the reaction time was $50 \mathrm{~min}$, the surface wear resistance was the best.

The possible reactions of MAO were as follows:

$$
\begin{gathered}
\mathrm{Al} \rightarrow \mathrm{Al}^{3}+3 \mathrm{e}^{-} \\
2 \mathrm{Al}^{3}+9 \mathrm{H}_{2} \mathrm{O} \rightarrow \mathrm{Al}_{2} \mathrm{O}_{3}+6 \mathrm{H}_{3} \mathrm{O}+6 \mathrm{e}^{-} \\
\mathrm{Al}_{2} \mathrm{O}_{3} \stackrel{\text { micro-arc }}{\longrightarrow} \gamma-\mathrm{Al}_{2} \mathrm{O}_{3} \\
\mathrm{Al}_{2} \mathrm{O}_{3} \stackrel{\text { micro-arc }}{\longrightarrow} \alpha-\mathrm{Al}_{2} \mathrm{O}_{3} \\
\gamma-\mathrm{Al}_{2} \mathrm{O}_{3} \stackrel{1150{ }^{\circ}-1200{ }^{\circ} \mathrm{C}}{\longrightarrow} \alpha-\mathrm{Al}_{2} \mathrm{O}_{3}
\end{gathered}
$$

For aluminum alloys, both $\alpha-\mathrm{Al}_{2} \mathrm{O}_{3}$ and $\gamma-\mathrm{Al}_{2} \mathrm{O}_{3}$ can be produced by the MAO reaction. ${ }^{24,25} \gamma-\mathrm{Al}_{2} \mathrm{O}_{3}$ could also be converted into $\alpha-\mathrm{Al}_{2} \mathrm{O}_{3}$ if the reaction temperature reached $1150{ }^{\circ} \mathrm{C} .{ }^{26,27}$ Therefore, the higher the content of $\alpha-\mathrm{Al}_{2} \mathrm{O}_{3}$, the better the binding strength and the higher the wear resistance of the ceramic film, indicating that both the reaction voltage and reaction time of the MAO had significant effects on the tribological properties. The long reaction time and the suitable reaction voltage resulted in a large thickness of the MAO film, a high binding strength, large roughness, small friction coefficient, and small wear volume.

\section{CONCLUSIONS}

With the increase in MAO time, the thickness was increased, and the growth rate decreased. With the increase in MAO voltage, the roughness of the film increased first and then decreased. With the increase in MAO time, the roughness of the film increases first and then decreases. 
For the same reaction voltage, the roughness first increased and then decreased with increasing reaction time.

With an increase in voltage, the intensity of the diffraction peak of $\alpha-\mathrm{Al}_{2} \mathrm{O}_{3}$ increased first and then decreased. As the $\alpha-\mathrm{Al}_{2} \mathrm{O}_{3}$ content increased, the binding strength and the friction coefficient increased.

With an increase in voltage and reaction time, the hardness of the film increased.

With an increase in voltage, the slope of the friction coefficient first decreased and then increased. With the increase in MAO time, the friction coefficient decreased first and then increased.

The higher the binding strength, the smaller the friction coefficient and the wear volume.

\section{Acknowledgement}

This research is supported by the Integration of Industry, Education and Research of Jiangsu Province (No. BY2016030-17) and the National Natural Science Foundation of China (51601079).

\section{REFERENCES}

${ }^{1}$ S. E. G. Dorman, Y. W. Lee, Effect of chromate primer on corrosion fatigue in aluminum alloy 7075, Procedia Eng., 10 (2011) 1220-1225, doi:10.1016/j.proeng.2011.04.20

${ }^{2}$ R. Canyook, P. Seubsom, J. Sang-ngean, T. Trirujirapapong, K. Taweesup, Influences of sealing solutions on anodized layer properties of 7075 aluminium alloy, Mater. Today, 5 (2018) 9483-9488, doi:10.1016/j.matpr.2017.10.128

${ }^{3}$ J. F. Peng, J. Xiao, Z. B. Xu, J. Zhang, Z. B. Cai, Z. P. Luo, M. H. Zhu, Study on the damage evolution of torsional fretting fatigue in a 7075 aluminum alloy, Wear, 402-403 (2018) 160-168, doi:10.1016/ j.wear.2018.02.008

${ }^{4}$ D. J. Kong, L. Hao, J. C. Wang, Effects of micro arc oxidation on fatigue limits and fracture morphologies of 7475 high strength aluminum alloy, J. Alloys Compd., 650 (2015) 393-398, doi:10.1016/ j.jallcom.2015.07.262

${ }^{5}$ G. P. Cao, R. G. Song, Microstructure and properties of ceramic coatings prepared by micro-arc oxidation on 7075 aluminum alloy. Mater. Res. Express, 5 (2018) 2, doi:10.1088/2053-1591/aaaca7

${ }^{6}$ D. J. Shen, G. L. Li, C. H. Guo, J. Zou, J. R. Cai, D. L. He, H. J. Ma F. F. Liu, Microstructure and corrosion behavior of micro-arc oxidation coating on 6061 aluminum alloy pre-treated by high-temperature oxidation, Appl. Surf. Sci., 287 (2013) 451-456, doi:10.1016/j.apsusc.2013.09.178

Q. P. Tran, T. S. Chin, Y. C. Kuo, C. X. Jin, T. Trung, C. V. Tuan, D. Q. Dang, Diamond powder incorporated oxide layers formed on 6061 Al alloy by plasma electrolytic oxidation, J. Alloys Compd., 751 (2018) 289-298, doi:10.1016/j.jallcom.2018.04.089

${ }^{8}$ I. V. Lukiyanchuk, V. S. Rudnev, V. G. Kuryavyi, D. L. Boduta, S. B. Bulanova, P. S. Gordienko, Surface morphology, composition and thermal behavior of tungsten-containing anodic spark coatings on aluminium alloy, Thin Solid Films, 446 (2004) 54-60, doi:10.1016/ S0040-6090(03)01318-X

${ }^{9}$ X. P. Lu, C. Blawert, D. Tolnai, T. Subroto, K. U. Kainer, T. Zhang, F. H. Wang, M. Zheludkevich, 3D reconstruction of plasma electrolytic oxidation coatings on $\mathrm{Mg}$ alloy via synchrotron radiation tomography, Corros. Sci., 139 (2018) 395-402, doi:10.1016/j.corsci. 2018.05.019
${ }^{10}$ W. B. Xue, X. L. Wu, X. J. Li, H. Tian, Anti-corrosion film on 2024/SiC aluminum matrix composite fabricated by microarc oxidation in silicate electrolyte, J. Alloys Compd., 425 (2006) 302-306, doi:10.1016/j.jallcom.2006.01.035

${ }^{11}$ A. R. Fatkullin, E. V. Parfenov, A. Yerokhin, D. M. Lazarev, A. Matthews, Effect of positive and negative pulse voltages on surface properties and equivalent circuit of the plasma electrolytic oxidation process, Surf. Coat. Technol., 284 (2015) 427-437, doi:10.1016/ j.surfcoat.2015.07.075

${ }^{12}$ Z. Q. Lin, H. J. Yu, S. Y. He, Y. N. He, C. Z. Chen, Effect of KOH on micro-arc oxidation coatings of $2 \mathrm{~A} 12$ aluminum alloys in $\mathrm{CH}_{3} \mathrm{COONa}-\mathrm{Na}_{2} \mathrm{WO}_{4}$ electrolyte, Surf. Rev. Lett., 21 (2014) 1450026, doi:10.1142/S0218625X14500267

${ }^{13}$ S. Maria, M. Marta, A Boualit, Active protective PEO coatings on AA2024: Role of phase composition of PEO coatings on AA2024 for in-situ LDH growth, Coatings, 7 (2017) 190, doi:10.3390/ coatings 7110190

${ }^{14}$ L. R. Krishna, K. R. C. Somaraju, G. Sundararajan, The tribological performance of ultra-hard ceramic composite coatings obtained through microarc oxidation, Surf. Coat. Technol., 163-164 (2003) 484-490, doi:10.1016/s0257-8972(02)00646-1

${ }^{15}$ G. Sabatini, L. Ceschini, C. Martini, Improving sliding and abrasive wear behaviour of cast A356 and wrought AA7075 aluminium alloys by plasma electrolytic oxidation, Mater. Des., 31 (2010) 816-828, doi:10.1016/j.matdes.2009.07.053

${ }^{16}$ A. Melhem, G. Henrion, T. Czerwiec, J. L. Briancon, T. Duchanoy, F. Brochard, T. Belmonte, Changes induced by process parameters in oxide layers grown by the PEO process on Al alloys, Surf. Coat. Technol., 205 (2011) S133-S136, doi:10.1016/j.surfcoat.2011.01. 046

${ }^{17}$ M. Mohedano, M. Serdechnova, M. Starykevich, S. Karpushenkov, A. C. Bouali, M. G. S. Ferreira, M. L. Zheludkevich, Active protective PEO coatings on AA2024: Role of voltage on in-situ LDH growth, Mater. Des., 120 (2017) 36-46, doi:10.1016/j.matdes. 2017.01.097

${ }^{18}$ E. Arslan, Y. Totik, E. E. Demirci, Y. Vangolu, A. Alsaran, I. Efeoglu, High temperature wear behavior of aluminum oxide layers produced by AC micro arc oxidation, Surf. Coat. Technol., 204 (2009) 829-833, doi:10.1016/j.surfcoat.2009.09.057

${ }^{19}$ Y. H. Gu, H. j. Ma, W. Yue, B. Tian, L. L. Chen, D. L. Mao, Microstructure and corrosion model of MAO coating on nano grained AA2024 pretreated by ultrasonic cold forging technology, J. Alloys Compd., 681 (2016) 120-127, doi:10.1016/j.jallcom.2016.03.196

${ }^{20}$ J. W. Zhang, Y. Z. Fan, X Zhao, R Ma, A Du, X. M. Cao, Influence of duty cycle on the growth behavior and wear resistance of microarc oxidation coatings on hot dip aluminized cast iron, Surf. Coat. Technol., 337 (2018) 141-149, doi:10.1016/j.surfcoat.2017. 12.064

${ }^{21}$ M. Treviño, N. F. Garza-Montes-de-Oca, A. Pérez, M. A. L. Hernández-Rodríguez, A. Juárez, R. Colás, Wear of an aluminium alloy coated by plasma electrolytic oxidation. Surf. Coat. Technol., 206 (2012) 2213-2219, doi:10.1016/j.surfcoat.2011.09.068

${ }^{22}$ H. J. Xie, Y. L. Cheng, S. X. Li, J. H. Cao, L. Cao, Wear and corrosion resistant coatings on surface of cast A356 aluminum alloy by plasma electrolytic oxidation in moderately concentrated aluminate electrolytes, T. Nonferr. Metal. Soc., 27 (2017) 336-351, doi:10.1016/S1003-6326(17)60038-4

${ }^{23}$ X. Yang, L Chen, XY Jin, JC Du, WB Xue, Influence of temperature on tribological properties of microarc oxidation coating on 7075 aluminium alloy at $25{ }^{\circ} \mathrm{C}-300{ }^{\circ} \mathrm{C}$. Ceram. Int., 45 (2019) 12312-12318, doi:10.1016/j.ceramint.2019.03.146

${ }^{24}$ P. Wang, T. Wu, Y. T. Xiao, J Pu, X. Y. Guo, J Huang, C. L. Xiang. Effect of $\mathrm{Al}_{2} \mathrm{O}_{3}$ Micro-powder Additives on the Properties of Micro-arc Oxidation Coatings Formed on 6061 Aluminum Alloy, J. Mater. Eng. Perform., 25 (2016) 3972-3976 doi:10.1007/s11665016-2255-5

${ }^{25}$ R. Q. Wang, Y. K. Wu, G. R. Wu, D. Chen, D. L. He, D. L. Li, An investigation about the evolution of microstructure and composition difference between two interfaces of plasma electrolytic oxidation coatings on Al, J. Alloys Compd., 753 (2018) 272-281, doi:10.1016/ j.jallcom.2018.04.077 
${ }^{26}$ J. L. Wang, W. Yang, D. P. Xu, X. F. Yao, Effect of $\mathrm{K}_{2} \mathrm{TiO}\left(\mathrm{C}_{2} \mathrm{O}_{4}\right)_{2}$ addition in electrolyte on the microstructure and tribological behavior of micro-arc oxidation coatings on aluminum alloy, Acta Metall. Sin. (Engl. Lett.), 30 (2017) 1109-1118, doi:10.1007/ s40195-017-0641-0

${ }^{27}$ R. Kamal Jayaraj, S. Malarvizhi, V. Balasubramanian, Optimizing the micro-arc oxidation (MAO) parameters to attain coatings with minimum porosity and maximum hardness on the friction stir welded AA6061 aluminium alloy welds, Defend Technol., 13 (2017) 111-117, doi:10.3969/j.issn.2214-9147.2017.02.007 